\title{
Nitrification of archaeal ammonia oxidizers in a high- temperature hot spring
}

\author{
Shun Chen, Xiaotong Peng, Hengchao Xu, and Kaiwen Ta \\ Institute of Deep-sea Science and Engineering, Chinese Academy of Sciences, Sanya 572000, China \\ Correspondence to: X.-T. Peng (xtpeng@sidsse.ac.cn)
}

Received: 1 September 2015 - Published in Biogeosciences Discuss.: 2 October 2015

Revised: 8 March 2016 - Accepted: 22 March 2016 - Published: 7 April 2016

\begin{abstract}
The oxidation of ammonia by microbes has been shown to occur in diverse natural environments. However, the link of in situ nitrification activity to taxonomic identities of ammonia oxidizers in high-temperature environments remains poorly understood. Here, we studied in situ ammonia oxidation rates and the diversity of ammonia-oxidizing Archaea (AOA) in surface and bottom sediments at $77^{\circ} \mathrm{C}$ in the Gongxiaoshe hot spring, Tengchong, Yunnan, China. The in situ ammonia oxidation rates measured by the ${ }^{15} \mathrm{~N}$ $\mathrm{NO}_{3}^{-}$pool dilution technique in the surface and bottom sediments were 4.80 and $5.30 \mathrm{nmol} \mathrm{N} \mathrm{g}^{-1} \mathrm{~h}^{-1}$, respectively. Real-time quantitative polymerase chain reaction (qPCR) indicated that the archaeal 16S rRNA genes and amoA genes were present in the range of 0.128 to $1.96 \times 10^{8}$ and 2.75 to $9.80 \times 10^{5}$ gene copies $\mathrm{g}^{-1}$ sediment, respectively, while bacterial amoA was not detected. Phylogenetic analysis of 16S rRNA genes showed high sequence similarity to thermophilic Candidatus Nitrosocaldus yellowstonii, which represented the most abundant operational taxonomic units (OTU) in both surface and bottom sediments. The archaeal predominance was further supported by fluorescence in situ hybridization (FISH) visualization. The cell-specific rate of ammonia oxidation was estimated to range from 0.410 to $0.790 \mathrm{fmol} \mathrm{N}$ archaeal cell ${ }^{-1} \mathrm{~h}^{-1}$, higher than those in the two US Great Basin hot springs. These results suggest the importance of archaeal rather than bacterial ammonia oxidation in driving the nitrogen cycle in terrestrial geothermal environments.
\end{abstract}

\section{Introduction}

Nitrogen is a key element controlling the species composition, diversity, dynamics, and functioning of many ecosystems (Vitousek et al., 1997). Despite of recent processes in our understanding of nitrogen cycling activities in soils, fresh and marine waters, and sediments (Francis et al., 2005; He et al., 2007; Beman et al., 2008; Jia and Conrad, 2009; Konneke et al., 2005; Nicol and Schleper, 2006), gaps in knowledge associated with high-temperature ecosystems have prevailed (C. L. Zhang et al., 2008). Recently, some studies have elucidated nitrogen metabolism and cycling in high-temperature hot spring ecosystems (Dodsworth et al., 2011b; Nishizawa et al., 2013; Gerbl et al., 2014). In such systems, there has been evidence of microbial communities oxidizing ammonia, the first and rate-limiting step of nitrification (Reigstad et al., 2008; Hatzenpichler et al., 2008). Since the occurrence of a putative archaeal $a m o A$ gene in hot spring environments was first reported by Weidler et al. (2007) and Spear et al. (2007), Thaumarchaeota possessing ammonia monooxygenase (AMO) have been obtained from some terrestrial hot springs in the USA, China, and Russia (Pearson et al., 2008; C. L. Zhang et al., 2008).

Previous studies targeting ammonia oxidation in hot springs mainly focused on archaeal amoA gene (AOA) via a variety of culture-independent approaches (e.g., 16S rRNA clone library, biomarkers; Weidler et al., 2007; Francis et al., 2007; C. L. Zhang et al., 2008; Jiang et al., 2010; Xie et al., 2014). The results from these studies suggested that ammonia-oxidizing Archaea (AOA) may be ubiquitous in high-temperature environments and even more abundant than their bacterial counterparts, which has led to a hypothesis that Archaea rather than bacteria drive ammonia oxidation in high-temperature hot spring environments. This hypothesis, 
however, still needs to be verified. Currently, our knowledge about the activity of AOA in such high-temperature environments is largely constrained, especially due to the data deficiency of ammonia oxidation rates (Reigstad et al., 2008; Dodsworth et al., 2011b; Li et al., 2015). In situ incubation experiments are urgently required to verify the potential activity of AOA and their contribution to ammonia oxidation in such high-temperature environments.

In this study, we selected the Gongxiaoshe hot spring at Tengchong geothermal field as a representative site to test the hypothesis that Archaea rather than bacteria drive ammonia oxidation in high-temperature hot spring environments. The reasons for choosing the Gongxiaoshe hot spring as the research site are: (1) Ammonia concentration in the Gongxiaoshe hot spring water is $102.61 \mu \mathrm{g} \mathrm{L}^{-1}$, thermodynamically favorable to ammonia oxidation (Shock et al., 2005); (2) Ammonia-oxidizing Archaea Candidatus Nitrosocaldus yellowstonii were dominant in the hot spring water and no AOB amoA genes were detected in the hot spring (Hou et al., 2013), indicating that the ammonia oxidation driven by Archaea might be active. Here, in combination of cultureindependent (fluorescence in situ hybridization, quantitative polymerase chain reaction (PCR), and clone library) and culture-dependent ( ${ }^{15} \mathrm{~N}$ pool dilution technique) approaches, we provide direct evidence that AOA are indeed responsible for the major portion of ammonia oxidation in hightemperature hot spring environments.

\section{Materials and methods}

\subsection{Site description and chemical measurements}

The Gongxiaoshe hot spring is a small pool with a diameter of $\sim 300 \mathrm{~cm}$ and a depth of $\sim 130 \mathrm{~cm}$ (Fig. 1). Hot spring water in the pool is well mixed and water chemistry shows no difference in different areas of the pool (G. Zhang et al., 2008). Sediments of the Gongxiaoshe hot spring are found to be only present at the margin of the pool and at the bottom of the pool, representing two typically sedimentary environments in this pool. The samples from the pool margins and sediments from the bottom of the spring, designated SS (surface sediments) and BS (bottom sediments), respectively, were collected using sterile equipment in April 2013. During transportation, all of the samples were packed with dry ice. They were then stored in a freezer at $-80^{\circ} \mathrm{C}$ in a lab for further analysis.

Temperature and $\mathrm{pH}$ were measured in situ in the hot water spring. Temperature was determined with an iButton thermometer (DS1922T, Dallas Semiconductor, USA). The $\mathrm{pH}$ was measured using a $\mathrm{pH}$ meter $\left(\right.$ SevenGo ${ }^{\mathrm{TM}} \mathrm{pH}$ meter $\mathrm{SG} 2$, Mettler Toledo, USA). Water samples for cation and anion analysis were filtered through a syringe filter with a $0.22 \mu \mathrm{m}$ filtration membrane; these samples were diluted 10 times with deionized water and stored in $100 \mathrm{~mL}$ polypropylene
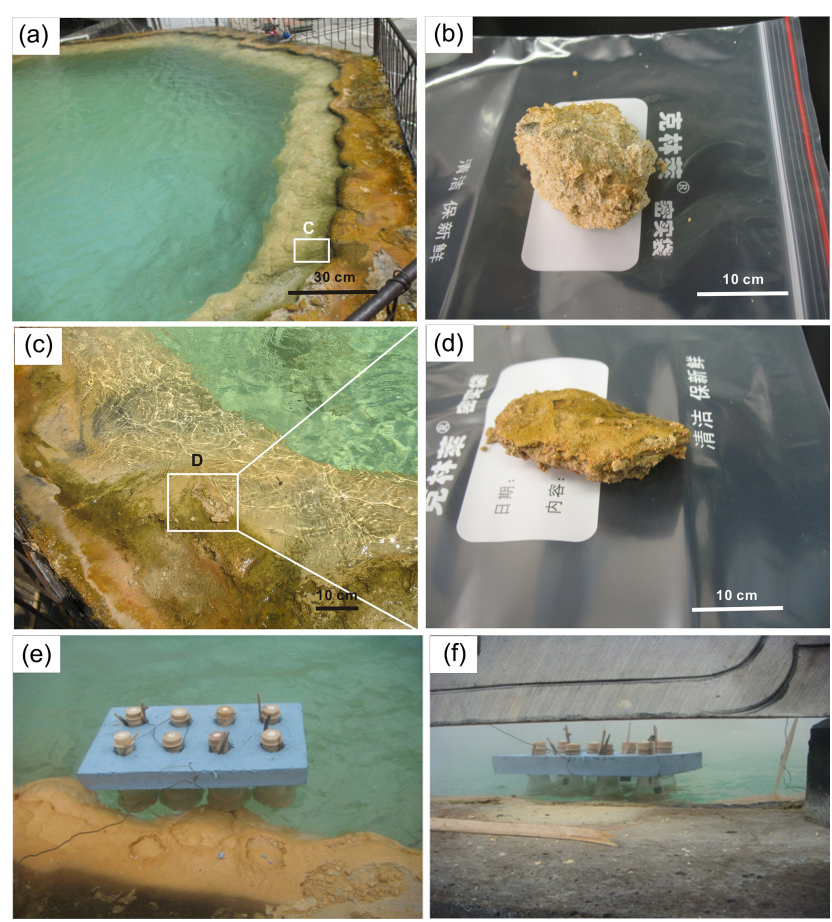

Figure 1. The Gongxiaoshe hot spring, located in the Ruidian geothermal area. (a) A full view of the spring; (b) bottom sediments of the hot spring, designated BS; (c) an enlarged view of the white box from Fig. 1a, surface sediments of the hot spring; (d) surface sediments of the hot spring designated as SS; and $(\mathbf{e}, \mathbf{f})$ in situ nitrification activity and potential nitrification activity experiments in the field.

bottles in the field because an analysis was carried out after 2 days. The cation concentrations were determined using an IRIS Advantage ICP-AES, whereas the anion $\left(\mathrm{F}^{-}\right.$, $\mathrm{SO}_{4}^{2-}, \mathrm{Cl}^{-}$) concentrations were determined using the Ion Chromatography System (DIONEX ICS-1500, Thermo Scientific, USA). The $\mathrm{HCO}_{3}^{-}$concentration was measured using the Gran titration method (Appelo and Postma, 1996). The $\mathrm{NH}_{4}^{+}-\mathrm{N}$ and $\mathrm{NO}_{3}^{-}-\mathrm{N}$ concentrations were determined using a nutrient analyzer (Micromac-1000, Partech, UK).

\section{$2.2{ }^{15} \mathrm{~N}$ stable isotope tracing of nitrification activity}

Gross $\mathrm{N}$ nitrification rates were determined in situ by the ${ }^{15} \mathrm{~N}$ pool dilution technique. All of the nitrification measurements were conducted in $500 \mathrm{~mL}$ polycarbonate culture flasks (Nalgene) with a silicone plug that contained $400 \mathrm{~mL}$ of mud ( $\sim 1 / 3$ sediment by volume). Two subsamples were collected from the bottom and surface sediments with $350 \mu \mathrm{L}$ of $\mathrm{K}^{15} \mathrm{NO}_{3}\left(485 \mu \mathrm{mol} \mathrm{L}{ }^{-1}\right.$, at $\left.10 \%{ }^{15} \mathrm{~N}\right)$. For each sample, two experiments were conducted to measure the in situ nitrification activity: A1 (SS slurry $+{ }^{15} \mathrm{NO}_{3}^{-}$) and A2 (BS slurry $+{ }^{15} \mathrm{NO}_{3}^{-}$). Meanwhile, potential nitrification activity was determined in the presence of high ammonium concentration: B1 (SS slurry $+{ }^{15} \mathrm{NO}_{3}^{-}+{ }^{14} \mathrm{NH}_{4}^{+}$) and B2 (BS slurry 
$+{ }^{15} \mathrm{NO}_{3}^{-}+{ }^{14} \mathrm{NH}_{4}^{+}$). Two pairs of duplicate reactors were set up in four experiments. The reactors were incubated near the in situ conditions of the hot spring water at $77^{\circ} \mathrm{C}$ for 30 and $120 \mathrm{~min}$. At certain time intervals (e.g., $30,120 \mathrm{~min}$ ), $80 \mathrm{~mL}$ aliquots were collected from the experimental reactors with sterile serological pipettes and transferred to acid-cleaned $250 \mathrm{~mL}$ polypropylene bottles. Prior to filtration, $40 \mathrm{~mL}$ of $\mathrm{KCl}(3 \mathrm{M})$ was added to each sample bottle, and the samples were shaken at $120 \mathrm{rpm}$ for $1 \mathrm{~h}$ and then centrifuged at $1600 \times g$ for $10 \mathrm{~min}$ (Reigstad et al., 2008). The supernatant was filtered through a syringe filter containing a $0.22 \mu \mathrm{m}$ filtration membrane; the supernatant was subsequently stored in acid-cleaned $60 \mathrm{~mL}$ polypropylene bottles at $4{ }^{\circ} \mathrm{C}$, and analysis was performed after 2 days.

In the laboratory, the concentrations of $\mathrm{NH}_{4}^{+}$and $\mathrm{NO}_{3}^{-}$ in the filtrate were determined by a nutrient analyzer (Micromac-1000, UK). The $\mathrm{NO}_{3}^{-}\left({ }^{15} \mathrm{NO}_{3}^{-}\right.$and $\left.{ }^{14} \mathrm{NO}_{3}^{-}\right)$ions of the filtrates were converted to $\mathrm{N}_{2} \mathrm{O}$ by denitrifying bacteria (Pseudomonas aureofaciens) lacking $\mathrm{N}_{2} \mathrm{O}$ reductase activity, and $\mathrm{N}_{2} \mathrm{O}$ was quantified by coupled gas chromatography isotope ratio mass spectrometry (GC-IRMS, Thermo Scientific, USA; Dodsworth et al., 2011a). The ammonia oxidation rates were calculated using the equations of Barraclough (1991) as were the concentrations and $\mathrm{N}$ isotope ratios of $\mathrm{NO}_{3}^{-}$in the samples incubated for 30 and $120 \mathrm{~min}$, respectively.

\subsection{DNA extraction and purification}

DNA was extracted by the SDS-based extraction method described by Zhou et al. (1996), with some modifications. Briefly, approximately $5 \mathrm{~g}$ samples were frozen with liquid nitrogen and milled three times. Then the powdered samples were mixed with $13.5 \mathrm{~mL}$ of DNA extraction buffer and $100 \mu \mathrm{L}$ of proteinase $\mathrm{K}\left(10 \mathrm{mg} \mathrm{mL}^{-1}\right)$ in tubes; these tubes were horizontally shaken at $225 \mathrm{rpm}$ for $30 \mathrm{~min}$ at $37^{\circ} \mathrm{C}$. After shaking, $1.5 \mathrm{~mL}$ of $20 \%$ SDS was added, and the samples were incubated in a water bath; the temperature of the water bath was maintained at $65^{\circ} \mathrm{C}$ for $2 \mathrm{~h}$. During this period, the tubes were subjected to gentle end-over-end inversions every 15 to $20 \mathrm{~min}$. The supernatant fluids were collected after subjecting the tubes to centrifugation at $6000 \times g$ for $10 \mathrm{~min}$ at room temperature; the collected supernatant tubes were subsequently transferred into $50 \mathrm{~mL}$ centrifuge tubes. The supernatant fluids were mixed with an equal volume of chloroform: isoamyl alcohol solution $(24: 1, v / v)$. The aqueous phase was recovered by centrifugation and precipitated with a 0.6 volume of isopropanol at room temperature; this process was carried out for at least $1 \mathrm{~h}$. Crude nucleic acids were obtained by centrifugation at $16000 \times g$ for $20 \mathrm{~min}$ at room temperature; these crude nucleic acids were washed with cold $70 \%$ ethanol and resuspended in sterile deionized water; the final volume of this solution was $100 \mu \mathrm{L}$. The crude nucleic acids were purified with a Cycle-Pure kit (Omega, USA). These crude nucleic acids were then resuspended in the elution buffer, and the final volume of the solution mixture was $50 \mu \mathrm{L}$; this solution was stored at $-80^{\circ} \mathrm{C}$.

\subsection{PCR and clone library construction}

The 16S rRNA gene was amplified with purified genomic DNA as templates using universal primers. The primer pairs A21F (5'-TTC CGG TTG ATC CYG CCG GA-3') and A958R (5'-YCC GGC GTT GAM TCC AAT T-3') were chosen for Archaea (Delong, 1992) and Eubac27F (5'-AGA GTT TGA TCC TGG CTC AG-3') and Eubac1492R (5'GGT TAC CTT GTT ACG ACT T-3') were chosen for bacteria (Lane, 1991). In a total volume of $50 \mu \mathrm{L}$, the reactions were performed using $1.25 \mathrm{U}$ of Taq DNA polymerase (Takara, Japan). The amplification conditions were as follows: an initial denaturation was carried out at $94^{\circ} \mathrm{C}$ for $4 \mathrm{~min}$, and then, the same denaturation was continued at $94^{\circ} \mathrm{C}$ for $1 \mathrm{~min}$. Thereafter, annealing was carried out at $55^{\circ} \mathrm{C}$ for $45 \mathrm{~s}$, while extension was conducted at $72^{\circ} \mathrm{C}$ for $60 \mathrm{~s}$; the process was repeated for 30 cycles, followed by a final extension step at $72^{\circ} \mathrm{C}$ for $10 \mathrm{~min}$. The PCR products were excised after being separated by gel electrophoresis; a gel-extraction kit (Omega, USA) was used to purify the products in accordance with the manufacturer's instructions. The purified PCR products were cloned into pMD20-T vectors (Takara, Japan) and transformed into competent Escherichia coli DH5 $\alpha$ cells. To select the positive clones, colony PCR was used to determine the presence of correctly sized inserts containing vector-specific primers M13f (5'-GTA AAA CGA CGG CCAG-3') and M13r (5'-CAG GAA ACA GCT ATGAC-3').

\subsection{Sequencing and phylogenetic analysis}

All of the clones were sequenced by the dideoxynucleotide chain-termination method. In this procedure, an ABI 3730 capillary electrophoresis sequencer (Applied Biosystem, Inc., USA) was coupled with the $\boldsymbol{T}$ vector universal primers M13f and M13r. The whole sequence of each clone was spliced using DNAMAN software (version 6.0), and the vector sequences were deleted; the presence of chimeras was checked using the Greengenes chimera check tool (Bellerophon server; Huber et al., 2004). The program DOTUR was used to determine the operation taxonomic units (OTU) for each sequence; $97 \%$ similarity was considered as the cutoff for the chimeric sequences. To find closely related sequences in the GenBank and EMBL databases for phylogenetic analysis, none of the chimeric sequences were submitted to the Advanced BLAST search program. Phylogenetic trees were constructed using the neighbor-joining method and the software MEGA (version 5.05). A bootstrap analysis was used to provide confidence estimates of the tree topologies. 


\subsection{Amplification of amoA (ammonia monooxygenase subunit A)-related sequences}

Archaeal amoA gene fragments were amplified using the primer pair Arch-amoAF ( $5^{\prime}$-STA ATG GTC TGG CTT AGA CG-3') and Arch-amoAR (5'-GCG GCC ATC CAT CTG TAT GT-3'; Francis et al., 2005). Bacterial amoA genes were also tested using the bacterial primer sets amoA $1 \mathrm{~F}$ (5'-GGG GTT TCT ACT GGT GGT-3') and amoA 2R (5'CCC CTC KGS AAA GCC TTC TTC- $3^{\prime}$; Rotthauwe et al., 1997). PCR cycling was performed by the method of Francis et al. (2005). In this method, PCR products from SS and BS were recovered from the gel slices using a gelextraction kit (Omega, USA) in accordance with the manufacturer's instructions. The purified PCR products from each type of sample were cloned into the pMD20-T vectors (Takara, Japan) and transformed into competent Escherichia coli DH5 $\alpha$ cells. Cloning and sequencing were performed according to the above-mentioned process. There were 40 50 randomly selected colonies per sample analyzed for the presence of insert archaeal amoA gene sequences.

\subsection{Quantification of 16S rRNA genes and amoA genes}

Archaeal and bacterial populations were determined by quantifying their 16S rRNA genes with 344F-518R (Øvreas et al., 1998) and 518F-786R primer pairs (Muyzer et al., 1993), respectively. In addition, the abundance of AOA and AOB were quantified using amo196F-amo277R (Treusch et al., 2005) and amoA-1F and amoA-2R (Rotthauwe et al., 1997) primers, respectively. All sample and standard reactions were performed in triplicate. The SYBR Green I method was used for this analysis. The $20 \mu \mathrm{L}$ reaction mixture contained $1 \mu \mathrm{L}$ of template DNA (10 ng), a $0.15 \mu \mathrm{M}$ concentration of each primer, and $10 \mu \mathrm{L}$ of Power SYBR Green PCR master mix (Applied Biosystems Inc., USA); this reaction mixture was analyzed with ROX and SYBR Green I. The PCR conditions were as follows: $10 \mathrm{~min}$ at $50^{\circ} \mathrm{C}, 2 \mathrm{~min}$ at $95^{\circ} \mathrm{C}$; 40 cycles consisting of $15 \mathrm{~s}$ at $95^{\circ} \mathrm{C}$ and $1 \mathrm{~min}$ at $60^{\circ} \mathrm{C} ; 15 \mathrm{~s}$ at $95^{\circ} \mathrm{C}, 1 \mathrm{~min}$ at $60^{\circ} \mathrm{C}$, and $15 \mathrm{~s}$ at $95^{\circ} \mathrm{C}$ to make the melting curve (Wang et al., 2009). Melting curve analysis was performed after amplification, and the cycle threshold was set automatically using system 7500 software v2.0 Patch 6. The efficiencies of the qPCR runs were 87.8$105.6 \%\left(R^{2}=0.992-0.999\right)$ for $16 \mathrm{~S}$ rRNA genes and $102 \%$ $\left(R^{2}=0.998\right)$ for AOA. Primers targeting different genes are listed in Table 1.

\subsection{Sample processing for FISH}

To visualize Crenarchaea cells in situ, fluorescence in situ hybridization (FISH) was performed according to the procedure described by Orphan et al. (2002, 2009). Small aliquots of sediment were fixed overnight at $4{ }^{\circ} \mathrm{C}$ using $2 \%$ formaldehyde in $1 \times$ PBS [145 mM NaCl, $1.4 \mathrm{mM} \mathrm{NaH}_{2} \mathrm{PO}_{4}, 8 \mathrm{mM}$
$\left.\mathrm{Na}_{2} \mathrm{HPO}_{4}(\mathrm{pH}=7.4)\right]$; these aliquots of sediments were washed twice with $1 \times \mathrm{PBS}$ and stored at $-20^{\circ} \mathrm{C}$ in ethanol: PBS $(1: 1, v / v)$ medium. The total supernatant was filtered through a polycarbonate filter (Millipore) under low vacuum ( $5 \mathrm{psi} ; 1 \mathrm{psi}=6.89 \mathrm{kPa})$. Filters were cut into suitably sized pieces and transferred onto untreated, round $2.54 \mathrm{~cm}$ glass slides. The transfer of filters onto glass slides was performed according to the procedure described by Murray et al. (1998). In this process, $5 \mu \mathrm{L}$ of a $1 \times$ PBS solution was spotted onto a glass slide that was scored with a diamond pen prior to mapping, and half of the freshly prepared filter was used to invert the sample onto the slide; this inverted sample was then airdried. Prior to FISH, the samples on the glass slides were treated with an $\mathrm{EtOH}$ dehydration series (50, 75, and $100 \% \mathrm{EtOH})$, dried, and stored at $-20^{\circ} \mathrm{C}$. Hybridization and wash buffers were prepared according to the procedure described by Pernthaler et al. (2001). Here, $20 \mu \mathrm{L}$ of hybridization buffer containing 35 or $20 \%$ formamide was added to the samples on the glass slides. FITC-labeled oligonucleotide Cren679 probe described by Labrenz et al. (2010), was added to the hybridization buffer so that the final solution had a concentration of $5 \mathrm{ng} \mu \mathrm{L}^{-1}$.

The hybridization mixtures on the slides were incubated for $1.5 \mathrm{~h}$ at $46^{\circ} \mathrm{C}$ in a premoistened chamber. After hybridization, the slides were transferred into a preheated wash buffer and incubated for an additional $15 \mathrm{~min}$ at $48^{\circ} \mathrm{C}$. The samples were rinsed in distilled water and airdried in the dark. The microscopic images of the hybridized samples were recorded on a Leica Imager (Leica, DMI 4000B, Germany).

\subsection{Nucleotide sequence accession numbers}

The clone libraries for archaeal communities (21F-958R), bacterial communities (27F-1492R), and archaeal amoA genes (amoAF-amoAR) were constructed. All of the smallsubunit rRNA gene sequences and the $a m o A$ sequences were deposited in the GenBank/EMBL nucleotide sequence database under the following accession numbers: from KP784719 to KP784760 for partial 16S rRNA gene sequences and from KP994442 to KP994448 for the amoA sequences.

\section{Results}

\subsection{Water chemistry}

The hot spring water $(\mathrm{pH}=7.7)$ contained $\mathrm{Ca}(20.25)$, $\mathrm{K}$ (41.97), $\mathrm{Mg}$ (3.986), $\mathrm{Na}$ (313.3), $\mathrm{SiO}_{2}$ (130.3), $\mathrm{HCO}_{3}^{-}\left(963 \mathrm{mg} \mathrm{L}^{-1}\right), \quad \mathrm{NH}_{4}^{+}-\mathrm{N}\left(102.61 \mu \mathrm{g} \mathrm{L}^{-1}\right), \mathrm{NO}_{3}^{-}-\mathrm{N}$ $\left(7.68 \mu \mathrm{L} \mathrm{L}^{-1}\right), \mathrm{F}^{-}\left(9.158 \mathrm{mg} \mathrm{L}^{-1}\right), \mathrm{Cl}^{-}\left(418.9 \mathrm{mg} \mathrm{L}^{-1}\right)$, and $\mathrm{SO}_{4}^{2-}\left(24.96 \mathrm{mg} \mathrm{L}^{-1}\right)$. The bottom water had a temperature of $77^{\circ} \mathrm{C}$, higher than the surface water that had a temperature of $55^{\circ} \mathrm{C}$. This hot spring was previously categorized as 
Table 1. FISH probe and PCR primer pairs used in this study.

\begin{tabular}{|c|c|c|c|c|c|}
\hline Application & $\begin{array}{l}\text { Probe/ } \\
\text { primer set }\end{array}$ & Specificity & Sequence $\left(5^{\prime}-3^{\prime}\right)$ & $\begin{array}{l}\mathrm{FA}(\%) / \\
\operatorname{AT}\left({ }^{\circ} \mathrm{C}\right)^{*}\end{array}$ & Reference \\
\hline FISH & Cren679 & Crenarchaeota & TTTTACCССТTCCTTCCG & 35 & Labrenz et al. (2010) \\
\hline \multirow[t]{6}{*}{ qPCR } & $518 \mathrm{~F}$ & \multirow[t]{2}{*}{ Bacteria } & CCAGCAGCCGCGGTAAT & \multirow[t]{2}{*}{57} & \multirow[t]{2}{*}{ Muyzer et al. (1993) } \\
\hline & $786 \mathrm{R}$ & & GATTAGATACCCTGGTAG & & \\
\hline & $344 \mathrm{~F}$ & \multirow[t]{2}{*}{ Archaea } & ACGGGGCGCAGCAGGCGCGA & \multirow[t]{2}{*}{60} & \multirow[t]{2}{*}{ Øvreas et al. (1998) } \\
\hline & $518 \mathrm{R}$ & & ATTACCGCGGCTGCTGG & & \\
\hline & amo $196 \mathrm{~F}$ & \multirow{2}{*}{$\begin{array}{l}\text { Archaeal } \\
\text { amoA }\end{array}$} & GGWGTKCCRGGRACWGCMAC & \multirow[t]{2}{*}{60} & \multirow[t]{2}{*}{ Treusch et al. (2005) } \\
\hline & amo277R & & CRATGAAGTCRTAHGGRTADCC & & \\
\hline \multirow[t]{8}{*}{ Clone library } & $\mathrm{A} 21 \mathrm{~F}$ & \multirow[t]{2}{*}{ Archaea } & TTCCGGTTGATCCYGCCGGA & \multirow[t]{2}{*}{55} & \multirow[t]{2}{*}{ Delong (1992) } \\
\hline & A958R & & YCCGGCGTTGAMTCCAATT & & \\
\hline & Eubac27F & \multirow[t]{2}{*}{ Bacteria } & AGAGTTTGATCCTGGCTCAG & \multirow[t]{2}{*}{55} & \multirow[t]{2}{*}{ Lane (1991) } \\
\hline & Eubac1492R & & GGTTACCTTGTTACGACTT & & \\
\hline & Arch-amoAF & \multirow{4}{*}{$\begin{array}{l}\text { Archaeal } \\
\text { amoA } \\
\text { Bacterial } \\
\text { amoA }\end{array}$} & STAATGGTCTGGCTTAGACG & \multirow[t]{2}{*}{53} & \multirow[t]{2}{*}{ Francis et al. (2005) } \\
\hline & Arch-amoAR & & GCGGCCATCCATCTGTATGT & & \\
\hline & amoA $1 \mathrm{~F}$ & & GGGGTTTCTACTGGTGGT & \multirow[t]{2}{*}{60} & \multirow[t]{2}{*}{ Rotthauwe et al. (1997) } \\
\hline & amoA 2R & & CCCCTCKGSAAAGCCTTCTTC & & \\
\hline
\end{tabular}

* FA: formamide; AT: annealing temperature.

a $\mathrm{Na}-\mathrm{HCO}_{3}$ spring due to the high concentration of alkaline metal ions (K, Na, and $\mathrm{Ca}$; G. Zhang et al., 2008).

\subsection{Ammonia oxidation rates}

In the surface and bottom sediments (without $\mathrm{NH}_{4}^{+}$stimulation), the near in situ rates of ammonia oxidation were estimated to be $4.80 \pm 0.2$ and $5.30 \pm 0.5 \mathrm{nmol} \mathrm{N} \mathrm{g}^{-1} \mathrm{~h}^{-1}$ using ${ }^{15} \mathrm{~N}-\mathrm{NO}_{3}^{-}$pool dilution technique, respectively. In the meantime, the nitrate concentration increased from $2.84 \pm 2$ to $3.25 \pm 2 \mu \mathrm{M}$ in the surface sediments and from $2.33 \pm 3$ to $2.62 \pm 3 \mu \mathrm{M}$ in the bottom sediments, further providing evidence for strong nitrification activity under in situ conditions in the hot springs. Furthermore, the potential activity of ammonia oxidation was determined with ammonium amendments. The nitrate concentration increased significantly upon the addition of $\mathrm{NH}_{4}^{+}$, and the ammonia oxidation rates recorded in the surface sediments and bottom sediments (with $\mathrm{NH}_{4}^{+}$) were $5.70 \pm 0.6$ and $7.10 \pm 0.8 \mathrm{nmol} \mathrm{N} \mathrm{g}^{-1} \mathrm{~h}^{-1}$, respectively.

\subsection{Archaeal community composition and phylogenetic analysis}

A total of 152 archaeal clone sequences of 16S rRNA genes were obtained in this study. Phylogenetic analysis showed the distribution of the clone sequences into three monophyletic groups: Thaumarchaeota, Crenarchaeota, and Euryarchaeota (Fig. 4). In this study, the most abundant archaeal phylum was Thaumarchaeota. Among them, two phylotypes (SS-A19 and BS-A1) were the most dominant archaeal lineage, representing 89 and $86 \%$ of the cloned archaeal sequences in surface and bottom sediments, respec- tively. These sequences were closely related to the thermophilic, autotrophic, ammonia-oxidizing archaeal $\mathrm{Ca} . \mathrm{N}$. yellowstonii (de la Tarre et al., 2008). The seven archaeal OTUs found here belonged to Crenarchaeota, which contains sequences recovered from hydrothermal vents and hot spring environments. In addition, two phylotypes (BS-A47 and BSA8) that were branched with uncultured sequences belonged to Desulfurococcales, which was also recovered from sediments of the hot spring. Euryarchaeota also occurred in both the sediments, but with relatively low abundances. Phylotype BS-A80 is associated with Geoglobus ahangari, which belongs to Archaeoglobales and is capable of oxidizing organic acids (Kashefi et al., 2002). SS-A12, which represents four clones recovered from the surface sediments, showed $93 \%$ similarity to an uncultured archaeal clone that was recovered from the Spring River. SS-A47 belonged to the Thermoplasmatales that were $96 \%$ similar to their nearest neighbor sequence, which were collected from the Spring River. The other euryarchaeotal sequences BS-14 and BSA80 were similar to their uncultured counterparts (from 96 to $99 \%$ identity), which were mostly recovered from hightemperature geothermal environments.

\subsection{Community analysis of $\mathrm{AOA}$}

A total of 113 archaeal amoA gene fragments were obtained from the two samples. They were all branched within the four distinct clusters of archaeal amoA sequences: cluster Nitrosopumilus, Nitrososphaera, Nitrosotalea, and $\mathrm{Ni}$ trosocaldus (Fig. 5). Nitrosopumilus cluster contained phylotypes SS-AOA-4 and BS-AOA-22, which branched with large numbers of sequences recovered from the sediments 
(a)
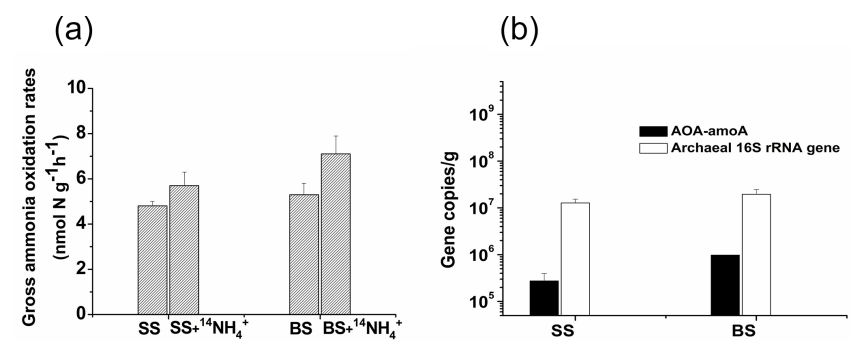

Figure 2. (a) Gross ammonia oxidation rates calculated from ${ }^{15} \mathrm{~N}$ $\mathrm{NO}_{3}^{-}$pool dilution experiments on amended (added ${ }^{14} \mathrm{NH}_{4}^{+}$) or unamended SS and BS sediment slurries. This defines that the amendment with " ${ }^{15} \mathrm{NO}_{3}$ " represents in situ nitrification activity, while ${ }^{15} \mathrm{NO}_{3}$ plus ${ }^{14} \mathrm{NH}_{4}$ is considered as potential nitrification activity. Bars represent the mean and standard error of the mean $(n=3)$ for 30 and 120 min incubation. (b) Abundance of archaeal 16S rRNA genes and archaeal amoA genes for SS and BS samples collected from the Gongxiaoshe hot spring. Data are expressed as gene copies per gram of sediment (dry weight). Error bars represent the standard deviation of the mean $(n=3)$.

and water samples in the marine or fresh environments. The other clade, cluster Nitrososphaera, has two phylotypes representing 44 sequences. OTU BS-AOA-62 contained 18 sequences, which was closely related to sequences from soil. The clone SS-AOA-76 clustered within clade Nitrososphaera and showed up to $99 \%$ sequence identity to an uncultured archaeon clone GHL2_S_AOA_19 (JX488447) obtained from lake sediment.

Cluster Nitrosotalea had one phylotype (SS-AOA-65) with 11 sequences (12\% of the total sequences). The closely related sequences in this cluster included characteristic crenarchaeotal group sequences that were obtained from alpine soil (with 98\% identity). Another clone, MX_3_OCT_18 (DQ501052), from estuary sediment was $96 \%$ similar.

Cluster Nitrosocaldus contained two phylotypes (BSAOA-15 and SS-AOA-50) with 34 sequences (30\% of the total sequences). They were closely related to the geothermal water sequences, with 95-99\% similarity. Furthermore, cluster Nitrosocaldus mainly represented previously described ThAOA/HWCG III (Prosser and Nicol, 2008). Notably, the recently reported $a m o A$ gene sequence of $C a$. N. yellowstonii (EU239961; De la Torre et al., 2008) showed $85 \%$ sequence identity to clones BS-AOA-15 and SS-AOA-50.

\subsection{Quantitative PCR}

The qPCR results (Fig. 2b) indicated that the abundance of the archaeal 16S rRNA gene in the two samples was similar, ranging from 1.28 to $1.96 \times 10^{7}$ gene copies $\mathrm{g}^{-1}$ of dry weight of sediments. However, the abundance of the bacterial $16 \mathrm{~S}$ rRNA gene varied greatly, ranging from $6.86 \times 10^{6}$ to $4.25 \times 10^{8}$ gene copies $g^{-1}$ of dry weight of sediments (Fig. S2 in the Supplement). The copy numbers of archaeal amoA genes in the surface and bottom sediments are

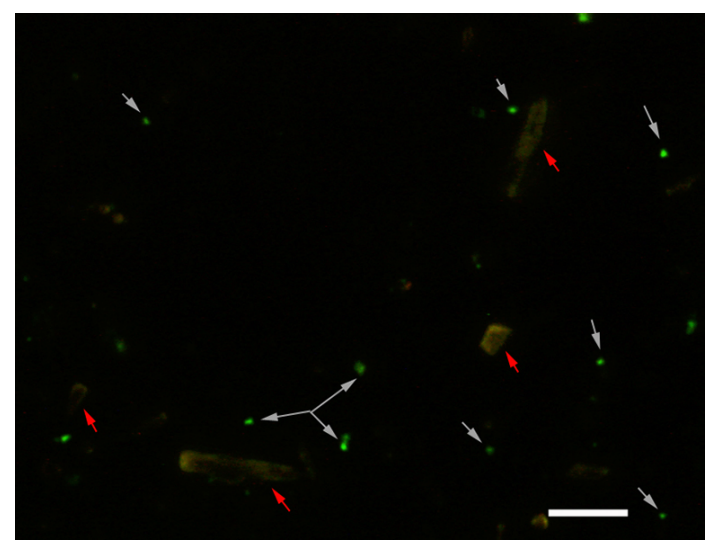

Figure 3. Epifluorescence photomicrograph of Crenarchaeota cells and cell aggregates. (White and red arrows show the cells and carbonate crystals, respectively. Scale bar corresponds to $20 \mu \mathrm{m}$.)

$2.75 \times 10^{5}$ and $9.80 \times 10^{5}$ gene copies $\mathrm{g}^{-1}$ sediment, respectively. The copy numbers of the archaeal $16 \mathrm{~S}$ rRNA genes in the bottom sediments were significantly higher than those of the bacterial 16S rRNA genes, with a ratio of 28.57. However, in surface sediments, the ratio of bacterial 16S rRNA genes to archaeal 16S rRNA genes is 3.32 .

\subsection{FISH}

FISH was used to analyze the relative abundance of Crenarchaea in two samples. As expected, most metabolically active Crenarchaea cells and aggregated cells were detected by FISH probes (Cren679; Fig. 3). Based on the qPCR results, a high abundance of Crenarchaea in the hot spring sediments harbored amoA genes, providing strong evidence supporting the important role of Crenarchaea in the oxidation of ammonia.

\subsection{Discussion}

\subsection{Environmental factors affecting the occurrence of ammonia-oxidizing microorganisms}

Temperature is likely a very important factor influencing microbial community structure. This interpretation is supported by the results of qPCR (Figs. 2b and S2). The sediment samples from the bottom of pool $\left(T=77^{\circ} \mathrm{C}\right)$ are dominated by Archaea, whereas the sediment samples from the margin of pool $\left(T=55^{\circ} \mathrm{C}\right)$ are dominated by bacteria. In addition, no AOB were detected in both bottom and margin samples, indicating that it might be difficult for AOB to inhabit in hightemperature hot spring environments (Lebedeva et al., 2005; Hatzenpichler et al., 2008). Additionally, the abundance of AOA amoA gene in bottom sediments is slightly higher than that in margin sediments, reflecting that although AOA can adapt to a wide range of temperature, higher temperature 


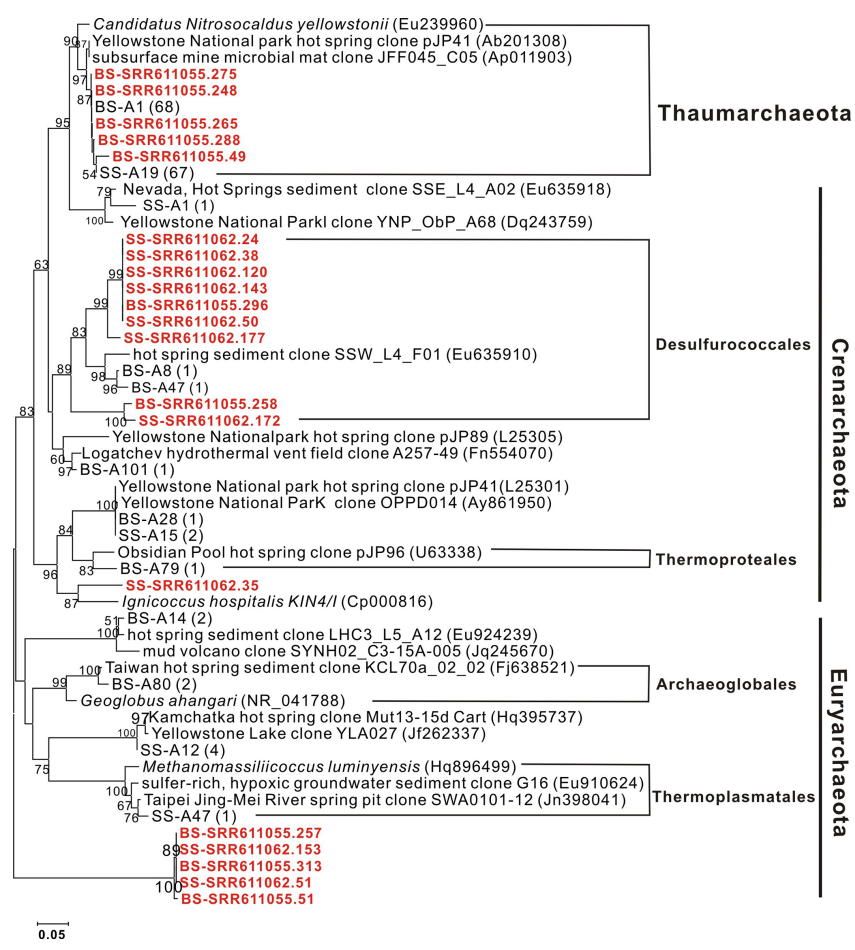

Figure 4. Archaeal phylogenetic tree based on 16S rRNA gene sequences, including various $16 \mathrm{~S}$ rRNA gene clones obtained from the Gongxiaoshe hot spring sediments (SS and BS) and cited some sequences from Hou et al. (2013; in red). The tree is constructed using the neighbor-joining method, and bootstrap confidence values over $50 \%$ (1000 replicates) are shown. The scale bar represents the expected number of changes per nucleotide position.

could be more favorable to the growth of AOA (de la Torre, et al., 2008; Hatzenpichler et al., 2008; Jiang et al., 2010).

Ammonia concentration may be another factor that influences the potential activity of AOA and AOB in hot springs. Because AMO in AOA has a much higher affinity for the substrate compared to a similar process in $\mathrm{AOB}$, the ability of AOA to compete for ammonia in oligotrophic hot spring environments is also substantially higher than that of AOB (Hatzenpichler et al., 2008). In the Gongxiaoshe hot spring, the ammonia concentration of $102.61 \mu \mathrm{g} \mathrm{L}^{-1}$ is lower compared to other hot springs with high ammonia concentrations. This relatively low ammonia concentration may possibly be responsible for the absence of AOB in the Gongxiaoshe hot spring.

\subsection{Composition and abundance of $\mathrm{AOA}$}

The rarefaction curves (Fig. S3) for archaeal 16S rRNA genes and amoA genes in the surface and bottom sediment samples reached a plateau, and their coverage values were relatively high (89-99\%). This result indicated that a large part of the archaeal/amoA diversity at this spring was probably included in the archaeal/amoA clone libraries. The ma-

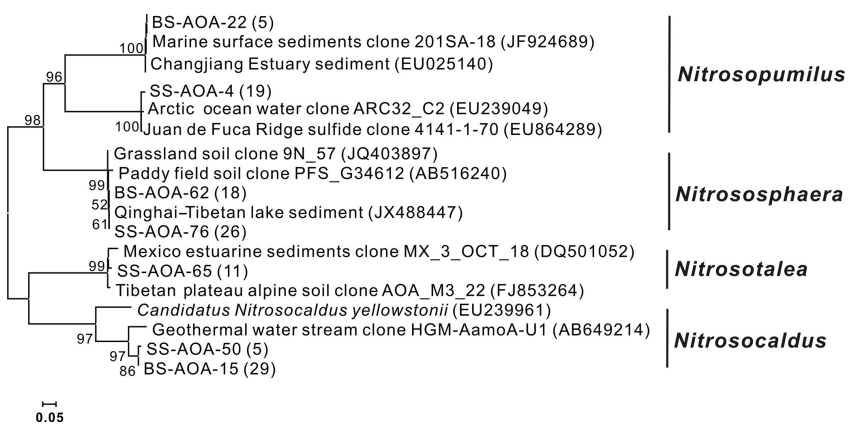

Figure 5. The phylogenetic tree of archaeal amoA genes is cloned from the Gongxiaoshe hot spring sediments (SS and BS). The tree is constructed using the neighbor-joining method, and bootstrap confidence values over $50 \%$ (1000 replicates) are shown. The scale bar represents the expected number of changes per nucleotide position.

jority of archaeal sequences were closely related to $C a$. $\mathrm{N}$. yellowstonii, a known AOA, which may be responsible for the oxidation of ammonia in this spring.

In this study, phylogenetic analyses of archaeal amoA genes showed that Candidatus Nitrosocaldus yellowstonii dominated in both of the samples. This result also agreed with previous hot spring observations reported by Dodsworth et al. (2011b) and Hou et al. (2013). According to the sequences retrieved from NCBI, Nitrosotalea and $\mathrm{Ni}$ trososphaera clusters were closely related to the cluster soil. One possibility is that some of the $a m o A$ genes obtained in this study may derive from soil AOA, particularly those sequences in cluster Nitrosotalea and cluster Nitrososphaera, which have been widely found in sediments and soils. Those AOA from soil might have evolved multiple times and have adapted to high-temperature environments. Based on the analysis of the real-time PCR and FISH methods, our data indicate that the abundance of AOA is relatively high in both samples. The archaeal amoA gene copy numbers ranged from 2.75 to $9.80 \times 10^{5}$ per gram dry weight of sediments in this study. This is comparable to the abundance in other hot water springs $\left[10^{4}-10^{5}\right.$ copies $^{-1}$ (Dodsworth et al., 2011b)], but is lower than the abundance of the archaeal amoA gene in nonthermal environments, such as paddy rhizosphere soil $\left[10^{6}-10^{7}\right.$ copies $^{-1}$ (Chen et al., 2008)] and marine sediments $\left[10^{7}-10^{8}\right.$ copies $\mathrm{g}^{-1}$ (Park et al., 2008)]. The bacterial amoA genes were not detected, indicating that AOB is absent or is a minority in this hot spring ecosystem. A predominance of archaeal amoA genes versus bacterial amoA genes indicated that ammonia oxidation may be due to the activity of Archaea in the Gongxiaoshe hot spring.

\subsection{The role of $\mathrm{AOA}$ in the nitrification of terrestrial geothermal environments}

In the surface and bottom sediments (without $\mathrm{NH}_{4}^{+}$), the ammonia oxidation rates calculated from the ${ }^{15} \mathrm{~N}^{-\mathrm{NO}_{3}^{-}}$pool di- 
lution data were $4.80 \pm 0.2$ and $5.30 \pm 0.5 \mathrm{nmol} \mathrm{N} \mathrm{g}^{-1} \mathrm{~h}^{-1}$, respectively. The ammonia oxidation rates recorded in the surface sediments and bottom sediments (with $\mathrm{NH}_{4}^{+}$) were $5.70 \pm 0.6$ and $7.10 \pm 0.8 \mathrm{nmol} \mathrm{N} \mathrm{g}^{-1} \mathrm{~h}^{-1}$, respectively. Moreover, the rates reported here were comparable with those observed in the two US Great Basin (GB) hot springs [5.50-8.60 nmol $\mathrm{N} \mathrm{g}^{-1} \mathrm{~h}^{-1}$ (Dodsworth et al., 2011b)] and in two acidic $\left(\mathrm{pH}=3, T=85^{\circ} \mathrm{C}\right)$ Iceland hot springs [2.80$7.00 \mathrm{nmol} \mathrm{NO}_{3}^{-} \mathrm{g}^{-1} \mathrm{~h}^{-1}$ (Reigstad et al., 2008)]. However, the rates reported in this study were lower than those observed in some wetland sediments and agricultural soils [85$180 \mathrm{nmol} \mathrm{N} \mathrm{g}{ }^{-1} \mathrm{~h}^{-1}$ (White and Reddy, 2003; Booth et al., 2005)].

The ammonia oxidation rates in bottom sediments (without $\mathrm{NH}_{4}^{+}$) were slightly higher than those observed in surface sediments (without $\mathrm{NH}_{4}^{+}$). This result agrees with the distribution of archaeal amoA genes, which were found to be in higher abundance in the bottom sediment than in the surface sediment. High abundance of ammonia-oxidizing Archaea corresponds to high ammonia oxidation rates, which were consistent with the results reported by Isobe et al. (2012). Compared with the incubation experiments unamended with $\mathrm{NH}_{4}^{+}$, the ammonia oxidation rate appeared to be stimulated after amendment with $\mathrm{NH}_{4}^{+}(1 \mathrm{M})$. There are indications that the ammonia concentration is an important factor affecting the rates of nitrification (Hatzenpichler et al., 2008).

To understand the relationship between the ammonia oxidation rates and abundances of $a m o A$ in the two samples, we specifically estimated the contribution of archaeal cells to nitrification. By assuming two amoA copies per cell (Bernander and Poplawski, 1997) and by comparing the ammonia oxidation rates with the qPCR results of AOA amoA per gram (however, some uncertainties of this method may still exist, with respect to the stage of cell cycle and the diversity of Archaea), the cell-specific nitrification rates were estimated to be 0.410 and $0.790 \mathrm{fmol} \mathrm{N}$ cell $^{-1} \mathrm{~h}^{-1}$ in the surface and bottom sediments of the hot spring, respectively. These results are much higher than those for AOA in US hot springs [0.008-0.01 fmol $\mathrm{N} \mathrm{cell}^{-1} \mathrm{~h}^{-1}$ (Dodsworth et al., 2011b)]. It is interesting that although the GB hot spring possesses higher amoA gene copies $\left(3.50-3.90 \times 10^{8}\right.$ gene copies $\mathrm{g}^{-1}$ of dry weight) and higher $\mathrm{NH}_{4}^{+}$concentration $\left(663 \mu \mathrm{g} \mathrm{L}^{-1}\right)$, it exhibits a lower cell-specific nitrification rate than the Gongxiaoshe hot spring. This may imply that both the abundance of AOA and the $\mathrm{NH}_{4}^{+}$concentration are not important factors that control the cell-specific nitrification rates in high-temperature hot spring environments. The difference in cell-specific nitrification rates between the Gongxiaoshe hot spring and the GB hot spring may reflect the difference of AOA population structure in those two hot springs (GubryRangin et al., 2011; Pester et al., 2012). In line with this AOA heterogeneity, cell-specific nitrification rates do not reflect the overall AOA abundance or $\mathrm{NH}_{4}^{+}$concentration in these AOA-dominated hot springs. Alves et al. (2013) reported a similar case where soil dominated by AOA (clade A) exhibited the lowest nitrification rates, in spite of harboring the largest AOA populations. These results also suggest the importance of cultivation studies for comparative analysis of environmentally representative AOA in a wide variety of hot springs.

\section{Conclusions}

Combination of ${ }^{15} \mathrm{~N}_{-} \mathrm{NO}_{3}^{-}$pool dilution and molecular analyses demonstrate that the oxidation of ammonia by AOA occurs actively in the high-temperature the Gongxiaoshe geothermal system. The presence of considerable in situ nitrification rates in the hot spring is likely due to two dominant groups that include phylotypes that are closely related to the autotrophic AOA $C a$. N. yellowstonii. The detection of archaeal amoA genes and the absence of AOB indicate that archaeal ammonia oxidizers, rather than AOB, significantly contribute to the nitrification in the Gongxiaoshe geothermal systems. Due to the AOA heterogeneity, cell-specific nitrification rates may not reflect the overall AOA abundance or $\mathrm{NH}_{4}^{+}$concentration in the AOA-dominated hot springs. Our results shed light on the importance of AOA in driving the oxidation of ammonia in high-temperature environments, which may be ubiquitous in other terrestrial hot springs on Earth.

\section{The Supplement related to this article is available online at doi:10.5194/bg-13-2051-2016-supplement.}

Acknowledgements. Financial support for this research came from the Knowledge Innovation Program of SIDSSE (SIDSSE-QN201409), the National Key Basic Research Program of China (2015CB755905), the Strategic Priority Research Program of the Chinese Academy of Sciences (XDB06020000) and the Natural Science Foundation of China (Grants 41272370). We are greatly indebted to two anonymous journal reviewers, H. Jiang, and the journal associate editor, Zhongjun Jia for their critical comments on an earlier version of this manuscript.

Edited by: Zhongjun Jia

\section{References}

Alves, R. J., Wanek, W., Zappe, A., Richter, A., Svenning, M. M., Schleper, C., and Urich, T.: Nitrification rates in Arctic soils are associated with functionally distinct populations of ammoniaoxidizing archaea, ISME J., 7, 1620-1631, 2013.

Appelo, C. A. J. and Postma, D.: Geochemistry, groundwater, and pollution, Balkema, Rotterdam, 1996.

Barraclough, D.: The use of mean pool abundances to interpret ${ }^{15} \mathrm{~N}$ tracer experiments, Plant Soil, 131, 89-96, 1991. 
Beman, J. M., Popp, B. N., and Francis, C. A.: Molecular and biogeochemical evidence for ammonia oxidation by marine crenarchaeota in the Gulf of California, ISME J., 2, 429-441, 2008.

Bernander, R. and Poplawski.: A Cell cycle characteristics of thermophilic archaea, J. Bacteriol., 179, 4963-4969, 1997.

Booth, M. S., Stark, J. M., and Rastetter, E.: Controls on nitrogen cycling in terrestrial ecosystems: a synthetic analysis of literature data, Ecol. Monogr., 75, 139-157, 2005.

Chen, X. P., Zhu, Y. G., Xia, Y., Shen, J. P., and He, J. Z.: Ammonia oxidizing archaea: important players in paddy rhizosphere soil?, Environ. Microbiol., 10, 1978-1987, 2008.

De la Torre, J., Walker, C., Ingalls, A., Koenneke, M., and Stahl, D.: Cultivation of a thermophilic ammonia oxidizing archaeon synthesizing crenarchaeol, Environ. Microbiol., 10, 810-818, 2008.

Delong, E. F.: Archaea in coastal marine environments, P. Natl. Acad. Sci. USA, 89, 5685-5689, 1992.

Dodsworth, J. A., Hungate, B., Torre, J., Jiang, H., and Hedlund, B. P.: Measuring nitrification, denitrification, and related biomarkers in continental geothermal ecosystems, Methods Enzymol., 486, 171-203, 2011 a.

Dodsworth, J. A., Hungate, B. A., and Hedlund, B. P.: Ammonia oxidation, denitrification and dissimilatory nitrate reduction to ammonium in two US Great Basin hot springs with abundant ammonia-oxidizing archaea, Environ. Microbiol., 13, 23712386, 2011b.

Francis, C. A., Roberts, K. J., Beman, J. M., Santoro, A. E., and Oakley, B. B.: Ubiquity and diversity of ammonia-oxidizing archaea in water columns and sediments of the ocean, P. Natl. Acad. Sci. USA, 102, 14683-14688, 2005.

Francis, C. A., Beman, J., and Kuypers, M.: New processes and players in the nitrogen cycle: the microbial ecology of anaerobic and archaeal ammonia oxidation, Appl. Environ. Microbiol., 1, 19-27, 2007.

Gerbl, F. W., Weidler, G. W., Wanek, W., Erhardt, A., and Stan-Lotter, H.: Thaumarchaeal ammonium oxidation and evidence for a nitrogen cycle in a subsurface radioactive thermal spring in the Austrian Central Alps, Front. Microbiol., 5, 1-17, doi:10.3389/fmicb.2014.00225, 2014.

Gubry-Rangin, C., Hai, B., Quince, C., Engel, M., Thomson, B. C., James, P., Schloter, M., Griffiths, R. I., Prosser, J. I., and Nicol, G. W.: Niche specialization of terrestrial archaeal ammonia oxidizers, P. Natl. Acad. Sci. USA, 108, 21206-21211, 2011.

Hatzenpichler, R., Lebedeva, E., Spieck, E., Stoecker, K., Richter, A., Daims, H., and Wagner, M.: A moderately thermophilic ammonia-oxidizing crenarchaeote from a hot spring, P. Natl. Acad. Sci. USA, 105, 2134-2139, 2008.

He, J., Shen, J., Zhang, L., Zhu, Y., Zheng, Y., Xu, M., and Di, H.: Quantitative analyses of the abundance and composition of ammonia-oxidizing bacteria and ammonia-oxidizing archaea of a Chinese upland red soil under long-term fertilization practices, Environ. Microbiol., 9, 2364-2374, 2007.

Hou, W. G., Wang, S., Dong, H. L., Jiang, H. C., Briggs, B. R., Peacock, J. P., Huang, Q. Y., Huang, L. Q., Wu, G., Zhi, X. Y., Li, W. J., Dodsworth, J. A., Hedlund, B. P., Zhang, C. L., Hartnett, H. E., Dijkstra, P., and Hungate, B. A.: A Comprehensive Census of Microbial Diversity in Hot Springs of Tengchong, Yunnan Province China Using 16S rRNA Gene Pyrosequencing, PLoS One, 8, e53350, doi:10.1371/journal.pone.0053350, 2013.
Huber, T., Faulkner, G., and Hugenholtz, P.: Bellerophon: a program to detect chimeric sequences in multiple sequence alignments, Bioinformaticsatics, 20, 2317-2319, 2004.

Isobe, K., Koba, K., Suwa, Y., Ikutani, J., Fang, Y. T., Yoh, M., Mo, J. M., Otsuka, S., and Senoo, K.: High abundance of ammoniaoxidizing archaea in acidified subtropical forest soils in southern China after long-term $\mathrm{N}$ deposition, FEMS Microbiol. Ecol., 80 , 193-203, 2012.

Jia, Z. J. and Conrad, R.: Bacteria rather than Archaea dominate microbial ammonia oxidation in an agricultural soil, Environ. Microbiol. 11, 1658-1671, 2009.

Jiang, H. C., Huang, Q. Y., Dong, H. L., Wang, P., Wang, F. P., Li, W. J., and Zhang, C. L.: RNA-based investigation of ammonia oxidizing archaea in hot springs of Yunnan Province, China, Appl. Environ. Microbiol., 76, 4538-4541, 2010.

Kashefi, K., Tor, J. M., Holmes, D. E., Gaw Van Praagh, C. V., Reysenbach, A. L., and Lovley, D. R.: Geoglobus ahangari gen. nov., sp. nov., a novel hyperthermophilic archaeon capable of oxidizing organic acids and growing autotrophically on hydrogen with Fe(III) serving as the sole electron acceptor, Int. J. Syst. Evol. Microbiol., 52, 719-728, 2002.

Konneke, M., Bernhard, A. E., de la Torre, J. R., Walker, C. B., Waterbury, J. B., and Stahl, D. A.: Isolation of an autotrophic ammonia-oxidizing marine archaeon, Nature, 437, 543-546, 2005.

Labrenz, M., Sintes, E., Toetzke, F., Zumsteg, A., Herndl, G., Seidler, M., and Jurgens, K.: Relevance of a crenarchaeotal subcluster related to Candidatus Nitrosopumilus maritimus to ammonia oxidation in the suboxic zone of the central Baltic Sea, ISME J., 4, 1496-1508, 2010.

Lane, D. J.: 16S/23S rRNA sequencing, in: Nucleic acid techniques in bacterial systematics, edited by: Stackebrandt, E. and Goodfellow, M., Wiley, Chichester, UK, 115-175, 1991.

Lebedeva, E. V., Alawi, M., Fiencke, C., Namsaraev, B., Bock, E., and Spieck, E.: Moderately thermophilic nitrifying bacteria from a hot spring of the Baikal rift zone, FEMS Microbiol. Ecol., 54, 297-306, 2005.

Li, H. Z., Yang, Q. H., Li, J., Gao, H., Li, P., and Zhou, H.: The impact of temperature on microbial diversity and AOA activity in the Tengchong Geothermal Field, China, Sci. Rep., 5, 1-12, doi:10.1038/srep17056, 2015.

Murray, A. E., Preston, C. M., Massana, R., Taylor, L. T., Blakis, A., Wu, K., and DeLong, E. F.: Seasonal and Spatial Variability of Bacterial and Archaeal Assemblages in the Coastal Waters near Anvers Island, Antarctica, Appl. Environ. Microbiol., 64, 25852595, 1998.

Muyzer, G, de Waal, E. C., and Uitterlinden, A. G.: Profiling of complex microbial populations by denaturing gradient gel electrophoresis analysis of polymerase chain reaction-amplified genes coding for 16S rRNA, Appl. Environ. Microbiol., 59, 695 700, 1993.

Nicol, G. W. and Schleper, C.: Ammonia-oxidising Crenarchaeota: important players in the nitrogen cycle?, Trends Microbiol., 14, 207-212, 2006.

Nishizawa, M., Koba, K., Makabe, A., Yoshida, N., Kaneko, M., Hirao, S., Ishibashi, J. I., Yamanaka, T., Shibuya, T., Kikuchi, T., Hirai, M., Miyazaki, J., Nunoura, T., and Takai, K.: Nitrificationdriven forms of nitrogen metabolism in microbial mat commu- 
nities thriving along an ammonium-enriched subsurface geothermal stream, Geochim. Cosmochim. Ac., 113, 152-173, 2013.

Orphan, V. J., House, C. H., Hinrichs, K. U., McKeegan, K. D., and DeLong, E. F.: Multiple archaeal groups mediate methane oxidation in anoxic cold seep sediments, P. Natl. Acad. Sci. USA, 99, 7663-7668, 2002.

Orphan, V. J., Turk, K. A., Green, A. M., and House, C. H.: Patterns of ${ }^{15} \mathrm{~N}$ assimilation and growth of methanotrophic ANME2 archaea and sulfate-reducing bacteria within structured syntrophic consortia revealed by FISH-SIMS, Environ. Microbiol., 11, 1777-1791, 2009.

Øvreas, L., Jensen, S., Daae, F. L., and Torsvik, V.: Microbial community changes in a perturbed agricultural soil investigated by molecular and physiological approaches, Appl. Environ. Microbiol., 64, 2739-2742, 1998.

Park, S. J., Park, B. J., and Rhee, S. K.: Comparative analysis of archaeal $16 \mathrm{~S}$ rRNA and $a m o A$ genes to estimate the abundance and diversity of ammonia-oxidizing archaea in marine sediments, Extremophiles, 12, 605-615, 2008.

Pearson, A., Pi, Y., Zhao, W., Li, W., Li, Y.-L., Inskeep, W., Perevalova, A., Romanek, C., Li, S. G., and Zhang, C. L.: Factors controlling the distribution of archaeal tetraethers in terrestrial hot springs, Appl. Environ. Microbiol., 74, 3523-3532, 2008.

Pernthaler, J., Glockner, F. O., Schonhuber, W., and Amann, R.: Fluorescence in situ hybridization with rRNA-targeted oligonucleotide probes, in: Methods in microbiology: Marine microbiology Academic Press, edited by: Paul, J. H., San diego, San Francisco, New York, Boston London, Sydney, Tokyo, 207-226, 2001.

Pester, M., Rattei, T., Flechl, S., Grongroft, A., Richter, A., Overmann, J., Reinhold-Hurek, B., Loy, A., and Wagner, M.: amoAbased consensus phylogeny of ammonia-oxidizing archaea and deep sequencing of amoA genes from soils of four different geographic regions, Environ. Microbiol., 14, 525-539, 2012.

Prosser, J. I. and Nicol, G. W.: Relative contributions of archaea and bacteria to aerobic ammonia oxidation in the environment, Environ. Microbiol., 10, 2931-2941, 2008.

Reigstad, L., Richter, A., Daims, H., Urich, T., Schwark, L., and Schleper, C.: Nitrification in terrestrial hot springs of Iceland and Kamchatka, FEMS Microbiol. Ecol., 64, 167-174, 2008.

Rotthauwe, J. H., Witzel, K. P., and Liesack, W.: The ammonia monooxygenase structural gene $a m o A$ as a functional marker: molecular fine-scale analysis of natural ammonia-oxidizing populations, Appl. Environ. Microbiol., 63, 4704-4712, 1997.

Shock, E. L., Holland, M., Meyer-Dombard, D. R., and Amend, J. P.: Geochemical sources of energy for microbial metabolism in hydrothermal ecosystems: Obsidian Pool, Yellowstone National Park, USA, in: Geothermal biology and geochemistry in Yellowstone National Park, edited by: Inskeep, W. P. and McDermott, T. R., 1, 95-112, 2005.
Spear, J. R., Barton, H. A., Robertson, C. E., Francis, C. A., and Pace, N. R.: Microbial Community Biofabrics in a Geothermal Mine Adit, Appl. Environ. Microbiol., 73, 6172-6180, 2007.

Treusch, A., Leininger, S.,, Kletzin, Schuster, S., Klenk, H., and Schleper, C.: Novel genes for nitrite reductase and Amo-related proteins indicate a role of uncultivated mesophilic crenarchaeota in nitrogen cycling, Environ. Microbiol., 7, 1985-1995, 2005.

Vitousek, P. M., Aber, J., Howarth, R. W., Likens, G. E., Matson, P. A., Schindler, D. W., Schlesinger, W. H., and Tilman, G. D.: Human alteration of the global nitrogen cycle: Causes and consequences, Ecological. Appl., 7, 737-750, 1997.

Wang, S., Xiao, X., Jiang, L., Peng, X., Zhou, H., Meng, J., and Wang, F.: Diversity and abundance of ammonia-oxidizing Archaea in hydrothermal vent chimneys of the Juan de Fuca Ridge, Appl. Environ. Microbiol., 75, 4216-4220, 2009.

Weidler, G. W., Dornmayr-Pfaffenhuemer, M., Gerbl, F. W., Heinen, W., and Stan-Lotter, H.: Communities of Archaea and Bacteria in a subsurface radioactive thermal spring in the Austrian Central Alps, and evidence of ammonia-oxidizing Crenarchaeota, Appl. Environ. Microbiol., 73, 259-270, 2007.

White, J. R. and Reddy, K. R.: Potential nitrification and denitrification rates in a phosphorous-impacted subtropical peatland, J. Environ. Qual., 32, 2436-2443, 2003.

Xie, W., Zhang, C. L., Wang, J., Chen, Y., Zhu, Y., Torre, J. R., Dong, H., Hartnett, H. E., Hedlund, B. P., and Klotz, M. G.: Distribution of ether lipids and composition of the archaeal community in terrestrial geothermal springs: impact of environmental variables, Environ. Microbiol., 17, 1-15, doi:10.1111/14622920.12595, 2014.

Zhang, C. L., Ye, Q., Huang, Z., Li, W., Chen, J., Song, Z., Zhao, W., Bagwell, C., Inskeep, W. P., Ross, C., Gao, L., Wiegel, J., Romanek, C. S., Shock, E. L., and Hedlund, B. P.: Global occurrence of archaeal amoA genes in terrestrial hot springs, Appl. Environ. Microb., 74, 6417-6426, 2008a.

Zhang, G., Liu, C. Q., Liu, H., Jin, Z., Han, G., and Li, L.: Geochemistry of the Rehai and Ruidian geothermal waters, Yunnan Province, China, Geothermics, 37, 73-83, 2008b.

Zhou, J., Bruns, M., and Tiedje, J.: DNA recovery from soils of diverse composition, Appl. Environ. Microbiol, 62, 316-322, 1996. 